\title{
THE ASSESSMENT OF PASTURE UTILISATION ON DAIRY FARMS
}

I. M. Brookes and C. W. Holmes

Department of Animal Science, Massey University

Abstract

The quantities of pasture utilised on New Zealand's predominantly pastoral dairy farms can be indirectly estimated from calculating the feed requirements of livestock on the farm and adjusting the total quantities consumed for feed purchased from off the farm. This method provides a logical and quantitative framework for analysing between farm differences in productivity and pasture utilisation.

The calculations require information regarding the number, breed and categories of stock farmed; the total production of milk or milkfat; the quantities of crops, hay and silage grown and/or conserved; and the quantities of purchased feeds consumed. Reliable tables of feed requirements are available for use in such calculations.

This method has been used to examine data collected in surveys of town supply and seasonal supply farms in Manawatu and South Auckland by Massey University and Lincoln College, respectively.

Comparisons between districts are unreliable because the surveys were conducted in different seasons and by different sampling methods. However, the differences between farm types were simila within districts and indicated lower stocking rates and milkfat production per hectare on town supply farms. There was a large reliance on the use of home grown pasture on all farms, but town supply farms used higher proportions of crops, hay and silage than did seasonal supply farms. A wide range existed between farms in the quantities of home grown feed consumed per hectare (4.9-18.0 tonnes DMha on town supply farms and 6.7-17.1 tonnes DM/ha on seasonal supply farms). This method of analysis. together with estimates of potential pasture production, may help to identity situations in which increases in pasture utilisation may be capable of increasing farm productivity.

Keywords: town supply, seasonal supply, grazing, conservation, supplements, farm productivity.

\section{INTRODUCTION}

The productivity of New Zealand dairy farms is usually expressed in terms of milk or milkfat produced per hectare. However, feed use on farms producing similar milk yields per hectare may be markedly different, either because of differences in the amounts of feed purchased from off the farm, or because of variations in feed conversion efficiency due to breed, yield per cow, and ratio of milking cows to dry stock. The use of constant factors (such as $25 \mathrm{~kg}$ DM eaten per $\mathrm{kg}$ milk fat produced) is, at best, a rough approximation and a more accurate estimate is obtained by calculating the quantities of metabolisable energy (ME) consumed by stock from data for live weight, rates of liveweight gain and milk production using predicted values for energy requirements (Baker 1982).

Ample evidence is now available to show that published energy requirements for dairy cattle (MAFF 1975) can be applied to grazing cattle with an acceptable level of accuracy (Fulkerson et a/. 1985).

We have therefore used data collected from a number of New Zealand dairy farms to estimate feed utilisation, in order to examine the usefulness of this system in the analysis of farm productivity. The calculations required have been made using a simple computer programme.

\section{METHODS}

\section{Farm Data}

Two sets of data were collected and used to estimate feed utilisation on dairy farms. The first set was obtained from 29 town supply (TS) and 18 seasonal supply (SS) farms in South Auckland for the 1983-84 season by the Agricultural Economics Research Unit, Lincoln College (Moffitt 1985). The second set was obtained from Manawatu farms for the 1985-86 
season. 23 TS farmers responded to a survey of all town supply farmers (52 in total) in the district, and 17 SS farmers responded to a survey conducted at the 1986 Massey University Dairyfarmers' Conference.

The information collected (where available) included:

- The numbers, breeds and categories of stock farmed.

- The numbers and categories of stock grazed off the farm, and the periods for which they were grazed away.

- The total milk or milkfat sold from the farm and the total quantity of milk fed to calves.

- The quantities of crops, hay and silage grown and/or consumed.

- The quantities of feed purchased from outside sources.

No data were available for animal live weight or rates of liveweight gain in growing cattle. These were therefore assumed to conform to target live weights suggested for New Zaland dairy stock (Holmes and Wilson 1984).

\section{Calculations}

The following measures of feed utilisation were calculated, in terms of GJ ME/ha, but were expressed as $\mathrm{kg}$ pasture equivalent dry matter (DM)/ha. The ME concentration in dairy pastures varies over a range of 9.8-I 1.8 MJ ME/kg DM throughout the year (Bryant and Trigg 1982 ), so a representative value of $11 \mathrm{MJ} / \mathrm{kg}$ DM has been adopted for these calculations.

Total Feed Consumed (T). This is estimated from the total number of stock carried, and their calculated annual ME requirements for the levels of production reported.

Total Purchased Feed Consumed (P). This is estimated from the annual ME requirements of stock grazing off the farm and the total quantities of feed purchased from outside sources. Estimates of the ME concentrations of feeds other than pasture were obtained from published tables of nutritive values for New Zealand feedstuffs (Holmes and Wilson 1984).

Total Home Grown Feed Consumed $(\mathbf{H})$. This is estimated as the difference between total feed intake $(T)$ and purchased feed consumed $(P)$. The quantity consumed as grazed pasture is estimated as the difference between the total home grown feed consumed and that consumed as home grown crops, hay and silage.

\section{Farm Data}

\section{RESULTS AND DISCUSSION}

Data obtained from the surveyed farms are shown in Table 1. The apparent differences between districts should be viewed with caution, because the surveys were conducted in different years, and for different samples of farms. Both 1983-84 and 1985-86 were good seasons for dairy production, as judged by national production levels -154 and $157 \mathrm{~kg}$ milk fat/cow (NZDB 1987), which were higher than in any other season. The district averages for Manawatu and South Auckland are similar to the national figures (NZDB 1985) and so the data suggest that the Manawatu farms surveyed were less representative of the district than those in South Auckland.

Nevertheless, the differences between TS and SS farms within districts were similar. The farms were similar in area, but TS farms carried $20 \%$ fewer cows and produced $17 \%$ less milk fat/hectare. Data from the Manawatu farms showed a higher proportion of Friesian cows on TS farms (98 vs 63\%) and a correspondingly higher milk yield per cow (4060 vs 2700 litres) despite similar milk fat yields. No such data were available from the South Auckland farms.

\section{Calculated Feed Consumption}

Data for total feed consumed $(T)$, purchased feed consumed $(P)$ and home grown feed consumed $(H)$ are presented in Table 2. Home grown feed accounted for $83-94 \%$ of the total feed consumption, with little apparent difference between TS and SS farms in the amount of purchased feed used.

Information collected about quantities of crops grown and hay and silage conserved can 
Table 1: Farm size and milkfat production (Mean and Range) on surveyed town and seasonal supply farms in Manawatu (1985-86) and South Auckland (1983-84).

\begin{tabular}{lcccc}
\hline & \multicolumn{2}{c}{ Town } & Seanawalu & \multicolumn{2}{c}{ Touth Auckland } \\
& 23 & 17 & 29 & Seasonal \\
\hline Number of farms & $73(28-124)$ & $74(34-137)$ & $59(33-113)$ & $60(23-112)$ \\
Area (ha) & $178(79-345)$ & $220(84-410)$ & $103(52-196)$ & $126(61-235)$ \\
Number of milking cows & $171(140-230)$ & $170(135-211)$ & $162^{*}(111-211)$ & $161(119-213)$ \\
Milkfat yield kg/cow & $432(206-713)$ & $511(323-724)$ & $292^{*}(182-492)$ & $353(226-503)$ \\
\hline \multicolumn{1}{c}{$\mathrm{kg} / \mathrm{ha}$} & & & \\
\hline
\end{tabular}

' Calculated from milk yields assuming a $4.2 \%$ milkfat test.

Table 2' Calculated annual quantities of feed consumed (Mean and Range) on surveyed town and seasonal supply farms in Manawatu (1985-86) and South Auckland (1963.84).

\begin{tabular}{lcccc}
\hline $\begin{array}{l}\text { Pasture Equivalent } \\
\text { DM Consumed } \\
\text { (tonnes/ha) }\end{array}$ & Town & Seasonal & Town & South Auckland \\
\hline Total & $13.6(7.4-24.6)$ & $14.5(11.3 .16 .1)$ & $6.9(6.4-14.1)$ & $9.8(6.6-131)$ \\
Purchased & $2.3(0-7.8)$ & $1.9(0-37)$ & $0.6(0-2.6)$ & $0.6 \quad(0-0.33)$ \\
Home Grown & & & & \\
Total & $11.3(6.7-18.0)$ & $126(8.7-17.1)$ & $8.3(4.9-13.8)$ & $9.2(6.7-11.7)$ \\
CropsiHay/Silage & $1.8(0.4-35)$ & $0.4(0-1.2)$ & $1.4(0.8-2.7)$ & $0.6(0-1) .0)$ \\
Grazed Pasture & $9.5(4.3-16.9)$ & $12.2(8.7-16.9)$ & $6.9(4.1-11.6)$ & $6.6(6.1-110)$ \\
\hline
\end{tabular}

be used to estimate how much of the home grown feed is derived from these sources and how much from grazed pasture. Such estimates need to be treated with caution because of likely variation in yields and wastage of crops, hay and siiage, which are not readily measured on farms. Assumed values based on New Zealand data (Drew and Fennessy 1980) have been used in these calculations.

However, it is apparent that TS farms provided, on average, a greater proportion of the home grown feed consumed as crops, hay or silage (16\%) than did SS farms (5\%).

Although the data collected in these surveys may in some instances be incomplete, it can be safely concluded that most of the home grown feed consumed (mean annual values of 11.3-I 2.6 tonnes DM/ha in Manawatu and 8.3-9.2 tonnes DM/ha in South Auckland) was in the form of pasture, either grazed or conserved. This provides the best estimate for comparison with data for pasture production, in order to investigate the efficiency of feed utilisation on farms.

Pasture production data is not available for individual farms, but values, measured by cutting before and after grazing with dairy cows have been reported from Massey University and Ruakura. Annual yields of between 11.5 and 13.3 tonnes DM/ha were recorded on two different soil types, without the use of fertiliser nitrogen, at Massey University in 1971-75 (Holmes and Wheeler 1975, Holmes and Halford 1976). At Fiuakura, values of between 12.4 and 16.3 tonnes DM/ha were recorded in 1982-1984 (Bryant et al. 1985). These results indicate possible levels of pasture productivity on dairy farms.

\section{CONCLUSIONS}

The methods outlined above, despite their acknowledged imperfections, provide the best available estimates of feed consumption and effective pasture productivity in pastoral farming systems. Hence they can provide a logical and quantitative framework within which to analyse farm productivity, the utilisation of pasture on the farm and the use of other types of feed. The calculations involved have been outlined, and in order for these to be valid, comprehensive sets of input data need to be provided. Where such data are not completely available, as in the surveys reported here, it is necessary to make assumptions based, in this case, on relevant research findings. 
Using this type of analysis, the survey data show a wide range of values between farms of from 6.7 to 18.0 tonnes DM/ha of home grown feed consumed within the Manawatu district, and between 54 and $96 \%$ of the total feed eaten being grazed pasture grown on the home farm. The use of this method of analysis may aid in the understanding of the reasons for such wide variation in feed use on dairy farms.

\section{Acknowledgements}

R. G. Moffitt for use of the Lincoln College survey data. A. H. Hughes and J. M. Rendel for assistance with the Manawatu survey and development of the computer programme. The participating farmers. The Town Milk Producers' Federation for financial support.

\section{References}

Baker RD. 1982. Estimating herbage intake from animal performance. In Leaver J.D. (Ed.). Herbage Intake Handbook. British Grassland Society.

Bryant A.M., Trigg T.E. 1982. The nutrition of the grazing dairy cow in early lactation. In: Macmillan K.L., Taula V.K. (Eds) Dairy Production from Pasture. N.Z. and Australian Society of Animal Production.

Bryant A.M., Cook M.A.S., Macdonald K.A. 1985. Comparative daily production of Jerseys and Friesians. Proceedings NZ Society of Animal Production 45: 7-11.

Drew K.R., Fennessy P.F. 1980. Supplementary Feeding. Occasional Publication No. 7. NZ Society of Animal Production.

Fulkerson W.J., Dobos R.C., Michell P.J. 1986. Relationship between predicted energy requirements and measured energy intake of daily cattle at pasture. Australian Journal of Experimental Agriculture 26: 523-526.

Holmes C.W.. Halford R.E. 1976. Some effects of nitrogen fertilizer and irrigation on the production of pasture on a town-supply dairy farm; N. 1 Dairy Unit, Massey University (1973-76). Department of Dairy Husbandry, Massey University.

Holmes C.W., Wheeler J.S. 1975. The production and utilization of pasture by dairy cows. No. 3. Daily Unit, 1971-74 Department of Dairy Husbandry, Massey University.

Holmes C.W.. Wilson G.F. (Eds) 1984. Milk Production from Pasture. Butterworths, Wellington. N.Z.

MAFF 1975. Energy allowances and feeding systems for ruminants. Ministry of Agriculture. Food and Fisheries. Technical Bulletin No. 33. H.M.S.O., London, U.K.

Moffitt R.G. 1985. A financial and economic survey of South Auckland town milk producers and factory supply dairy farmers 1983-84. Research Report No. 176. Agricultural Economics Research Unit, Lincoln College.

NZDB 1985. 61ș Livestock Improvement Report. 1984-85 Season. Livestock Improvement Division, NZ Dairy Board. NZDB 1987. Annual Report, May 1987. NZ Dairy Board. 